\title{
Converting Forest Biomass to Bioenergy for Improved Community Livelihoods: A Review
}

\author{
Derkyi Nana Sarfo Agyemang ${ }^{1, ~}$, Derkyi Mercy Afua Adutwumwaa ${ }^{2}$, Yankyera Joseph Kusi ${ }^{1}$ \\ ${ }^{1}$ Department of Energy and Petroleum Engineering, University of Energy and Natural Resources, Sunyani, Ghana \\ ${ }^{2}$ Department of Forest Science, University of Energy and Natural Resources, Sunyani, Ghana
}

\author{
Email address: \\ nana.derkyi@uenr.edu.gh (D. N. S. Agyemang), mercy.derkyi@uenr.edu.gh (D. M. A. Adutwumwaa), \\ joseph.yankyera@uenr.edu.gh (Y. J. Kusi) \\ ${ }^{*}$ Corresponding author
}

\section{To cite this article:}

Derkyi Nana Sarfo Agyemang, Derkyi Mercy Afua Adutwumwaa, Yankyera Joseph Kusi. Converting Forest Biomass to Bioenergy for Improved Community Livelihoods: A Review. International Journal of Energy and Environmental Science. Vol. 6, No. 2, 2021, pp. 16-28. doi: $10.11648 /$ j.ijees.20210602.11

Received: March 18, 2021; Accepted: March 30, 2021; Published: April 29, 2021

\begin{abstract}
A wide range of forest biomass from both natural and plantation forests constitutes an essential natural asset to a large number of households. The ever-increasing development of biofuels as a potentially sustainable and cleaner replacement for conventional fuels represents a key challenge for the forest industry and the opportunity for forest fringe communities. This, typifies a unique situation to understand the challenges and opportunities for designing sustainable bioenergy supply chains that require simultaneous consideration of economic, social, and environmental aspects. The objective of this study was to examine the conversion of forest biomass to bioenergy for improved community livelihoods. Desk study, content analysis and authors' personal experiences were employed in carrying out this study. The study finds that forest environ abounds with biomass as feedstock for bioenergy. Positively, there are different technologies in converting biomass to bioenergy. However, it calls for the technical know-how and other factors such as infrastructure, market, full participation of critical players and policy incentives to facilitate bioenergy enterprises at the local level. In conclusion, policies and support mechanisms on bioenergy in creating sustainable livelihoods should be the priority for most countries where biomass abounds and could be established to provide clean and efficient energy.
\end{abstract}

Keywords: Energy Conversion, Forest Industry, Sustainable Development, Livelihood, Fuelwood

\section{Introduction}

Bioenergy describes the energy source that uses the energy from the sun available in a biological matter $[1,2]$. Bioenergy technology could be traditional or modern. For modern bioenergy; wood or other energy crops are burned using power plants, in some cases, to generate either heat or electricity or both heat and electricity. Traditional bioenergy involves the burning of wood, charcoal or agricultural wastes in stores for heating and cooking. Other bioenergy forms are biofuels (fuels derived from biomass sources) which can be used for heating purposes and transportation.

The use of bioenergy has been a substantive contributor to meeting increasing global energy demand [3] and for related challenges with the traditional and widely used energy forms. Paramount among these related challenges are high levels of greenhouse gas (GHG) emissions and scarcity of fossil fuels [3]. For rural communities, it has created opportunities for socio-economic development; by way of improving waste and other resource management. The bioenergy sector has proven to be significant in keeping social, economic and environmental health with the overall goals of ensuring energy security. In doing so, different biomass materials undergo varied suitable conversion processes to produce bioenergy. These conversions are biochemical, mechanical and thermochemical [3, 4]. The biochemical conversion uses biological catalysts and enzymes and involves biological processes such as fermentation and anaerobic digestion $[3,5]$.

The mechanical conversion uses mechanical power and it involves processes such as briquetting, pelletization and oil extraction $[3,9]$. The thermochemical conversion uses heat and chemical catalysts and includes (but not limited to) 
combustion, gasification, pyrolysis, and torrefaction [3]. Some bioenergy technologies have cost-effective systems, use appropriate technologies, have determined optimal plant capacity, meet economic constraints, are reliable and can most important of all, improve the quality of life $[4,6,8,9]$. However, there are still some bioenergy technologies which are not commercially viable $[6,8,9]$. Typical examples of conversion products are dominant in the bioenergy industry: biogas, biodiesel and bioethanol. Biogas is a mixture of gases, mainly methane; which is produced through anaerobic digestion of organic material. Biodiesel is produced through mechanical pressing and solvent extraction techniques from seeds: soy, sunflower, rapeseed, jatropha, and palm. Bioethanol: is a vehicle fuel which is produced from crops: sorghum, sugarcane, cassava [9].

Aside the conversion methods used to transform energy products into higher quality forms of energy, some biomass materials are used directly. A typical example is the use of wood as wood fuel. Wood provides about $50 \%$ of African's primary energy. The use of wood is particularly significant in rural communities where no alternatives exist. On the other hand, charcoals are the cheapest fuel options available in the cities. This dynamic accounts for the unsustainable levels of harvesting in highly populated areas. A rise in Africa's energy demand undoubtedly calls for the need for renewable energies. Bioenergy usage has the most expansive land footprint in terms of all approaches to energy generation [9]. Beyond that, it is mostly considered as a critical driver of land grabbing resulting in community conflicts, human rights abuse, and forest impacts [9].

Globally, there has been a significant rise in the production and consumption of bioenergy; however, this is low in Africa [5]. Interestingly, $75 \%$ of the population in Sub-Saharan Africa rely on traditional biomass: charcoal, cow dung and wood for their energy needs. At the same time, these persons are not able to access electricity or any modern energy services [5]. Typical forms of bioenergy are biofuels which are efficient and contemporary derivatives of biomass conversion. To the average local person, traditional bioenergy provides solutions such as efficiency, opportunity to meet growing household energy demands, reduced poverty, increased income levels and mitigation of environmental degradation. It follows that energy and livelihoods security of people are fundamentally inter-related. Modern bioenergy is relevant in achieving sustainable development through the use of smallholder production and processing regimes. With these approaches, new domestic markets emerge, new cash incomes are generated, social well-being is created, novel technologies are adopted, land is sustainably used and there is a ground for economic transformation in rural areas $[5,6]$.

International communities have been interested in the social and economic relevance of the widespread use of renewable energy resources such as bioenergy. Countries like the United States of America have had their public policies and programs enhancing bioenergy development edged to promote energy security, economic growth and environmental improvement [7]. While doing so, the views, concerns and experiences of the local people have been marginalized despite their role of producing the relevant energy crops [8]. Rossi \& Hinrichs (2011) study found that "local and regional revitalization" is most desirable yet least expected [8]. Rossi \& Hinrichs [8] looked at the potential, challenges and tradeoffs related to agricultural bio-economy of communities and asserted there is skepticism concerning how agricultural bio-economy impacts society, an observable corporate control in agriculture is to blame.

Using forest biomass in renewable energy generation has related attention in the quest of responding to climate change and increasing demands in the energy industry [3]. This requires the availability of local resources and the possibility to transform the resources into forms relevant to end users. Aside from this, the approach should be one which requires a low capital investment.

The objective of this chapter was to examine the conversion of forest biomass to bioenergy for improved community livelihoods. Desk study, content analysis and authors' personal experiences were employed in carrying out this study. After the introduction, we elaborate on three issues- i) overview of biomass and bioenergy globally and nationally; ii) technologies available for biomass conversion to bioenergy; iii) forest biomass energy-based enterprises and policies to sustain such enterprises and then end with a conclusion.

\section{Overview of Forest Biomass and Bioenergy Outlook}

\subsection{Contribution of Forest Biomass to Bioenergy}

Forests grow around the world, containing diversity of many wood species [10]. The major forest types of Africa are dry tropical forests in the Sahel, Eastern and Southern Africa, moist-tropical forests in Western and Central Africa, subtropical forest and woodlands in Northern Africa, and mangroves in coastal zones of the southern end [10]. Figure 1 shows the forest cover of the world. Both the natural forest and plantation forest contribute significantly to the world's energy use and a source of renewable energy for the energy sector $[10,11]$. One of the ideal options to reduce overreliance on natural forest for bioenergy, is to increase the establishment of dedicated plantation forests specifically to produce wood for bioenergy. The forest trees serve as a source of energy through the conversion of woody biomass into fuel for industrial, commercial or households use. In 2012, biomass from forests and other areas with trees contributed $49 \mathrm{EJ}$ to the global energy supply. The greatest share of this biomass is used in Asia and Africa. The future potential of wood for energy depends on three key aspects: a better use and management of existing forests; a better use of the by-products or residues of trees in non-forest areas for bioenergy instead of dumping a huge share of this material as it is done in many parts of the world today; the planting of new forests in order to compensate for the losses of forest in some regions, to increase the global forest area again and use 
part of this additional production for energy [WBA]. Figure 2 and Figure 3 show a natural forest and plantation forest respectively. About $14 \%$ of primary world energy is obtained from the forest [12]. According to FAO, the majority of bioenergy are from forests, woodlands and agricultural land $[10,13]$. In developing countries, about 80 per cent of total wood use is obtained from wood fuel [10].

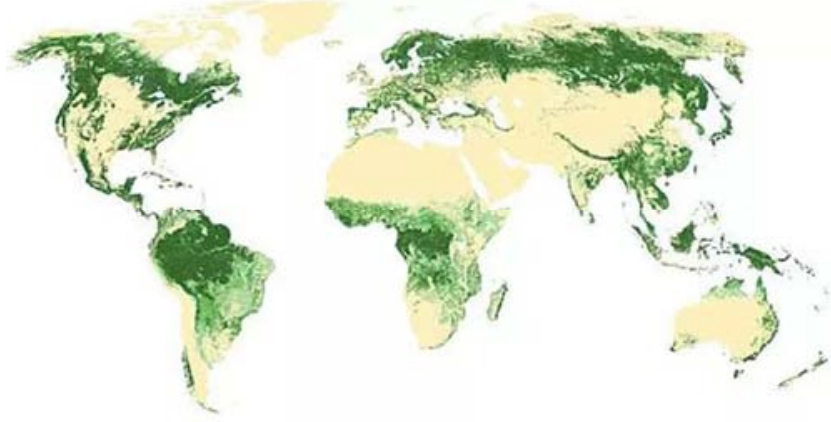

Figure 1. Map of worldwide forest cover. Source FAO.

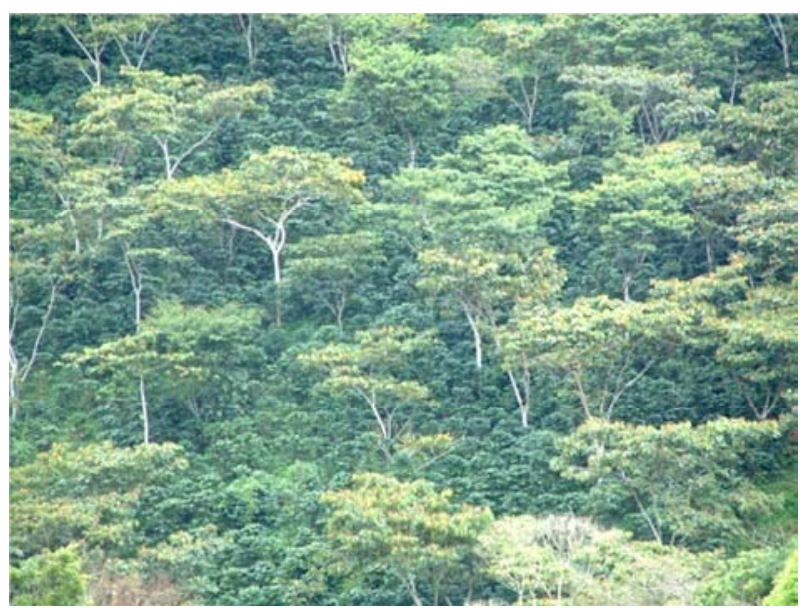

Figure 2. Natural forest. Source: https://unsplash.com/photos/.

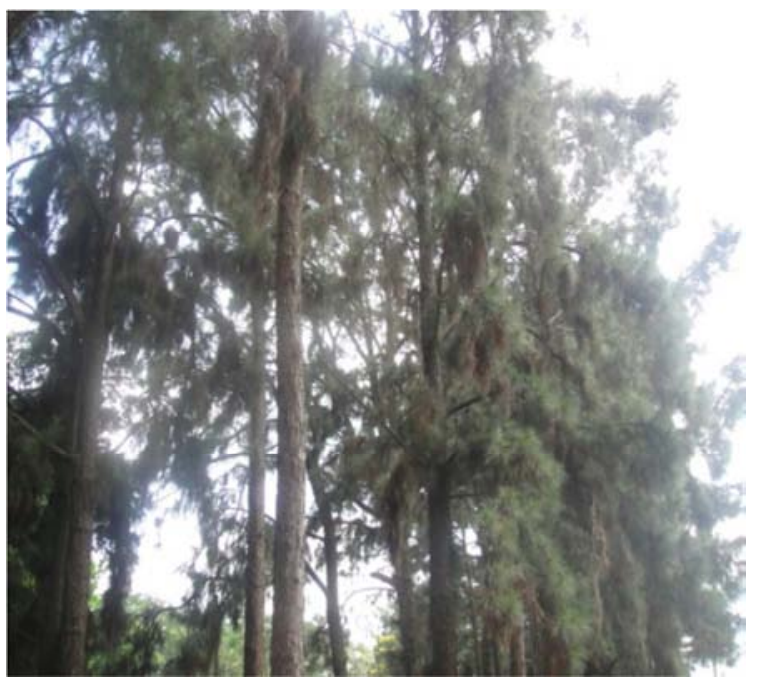

Figure 3. Plantation forest. Source: Authours'own.

Developed countries are increasingly using biomass as a source of their energy while the European Union, for instance, generates more than $100,000 \mathrm{GWh}$ of electricity from biomass every year and much of it is derived from trees [14]. In Finland, 23\% of the energy is derived from wood, which is more than the total generating capacity of most countries in Africa [14]. In Ghana, wood fuels serve as the main energy resources constituting $90-95 \%$ of the total primary energy [15, $16]$. The bulk of the country's primary energy supply comes from biomass [16]. Biomass produced from plantations managed for timber is one source of woody biomass for energy [12]. Wood processing industries are also sources of biomass for energy, and from the work done by Derkyi et al, 2011 [17], annual wood residues generated in three wood processing mills in Ghana ranged from $19,230 \mathrm{~m} 3$ to 32,610 $\mathrm{m}^{3}$. Logging residues are also abundant on forest floors, and the officials of the Ghana Forestry Commission motivate contractors to utilize the biomass residue [18]. The tropical high forest zone is thus, an essential source of biomass for energy [19].

The studies in Ghana by Amuah, 2011 [20], revealed that an estimated 14 million $\mathrm{m} 3$ of wood are consumed for energy production. Bioenergy systems contribute significantly to the reduction of greenhouse gas emissions when they are replaced for fossil fuel in energy production [12]. Literature refers different forest trees and forest types that are used by local communities as fuelwood or firewood across the globe $[10,19,21,22,23]$. In Ghana, some forest tree species rural households prefer for firewood and charcoal in the semideciduous ecological zone are Magaritaria discoidea (Papea), Celtis zenkeri (Esa), Triplochiton scleroxylon (Wawa) Ficus exasperate (Nyankyerene) and Pericopsis elata (Kokrodua) [19]. Similarly, species such as Zanthoxylon xanthoxyloides (Kaanto), Azadirachta indica (neem), Alstonia boonei (Nyamedua) and Morus mesozygia (Wonton) are preferred by rural households in the coastal savanna ecological zone [19].

\subsection{Bioenergy Outlook, Access and Development}

Universal access to inexpensive, dependable, and modern energy including bioenergy will progressively be required for the progress and development across Africa. As such, energy demand and supply will be a key pillar in national industrialization policy and strategies. In this regard, bioenergy is considered in most developed and developing countries as one among several paths for diversification of energy sources. The role of bioenergy may be more critical in Sub-Saharan Africa, where so many people are entirely dependent on access to land and its products, which include traditional forms of bioenergy, to survive. [24]

The global context is one in which new greener energy sources are urgently needed. Figure 4 shows a global biomass potential based on different sources, with indication of substantial reliance on biomass [25]. Current sources in the global primary energy mix show heavy biomass dependence in non-OECD (Organisation for Economic Co-operation and Development) countries, than in OECD countries, as shown in Figures 5 and 6 [25]. 


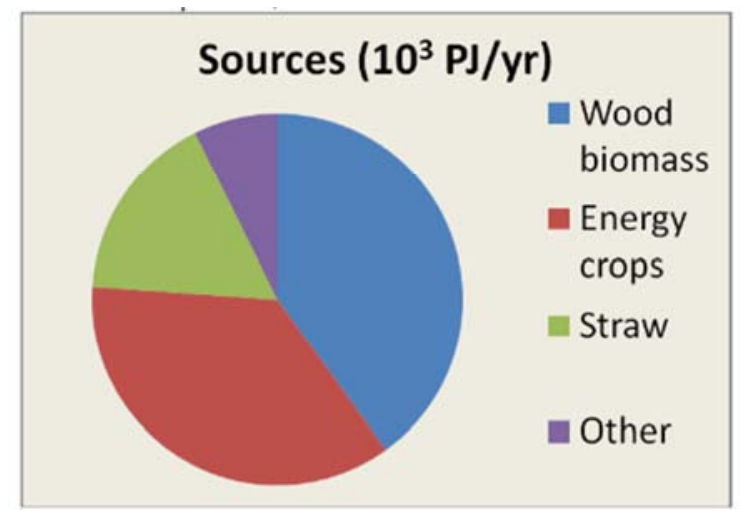

Figure 4. Global biomass potential based on different sources [25].

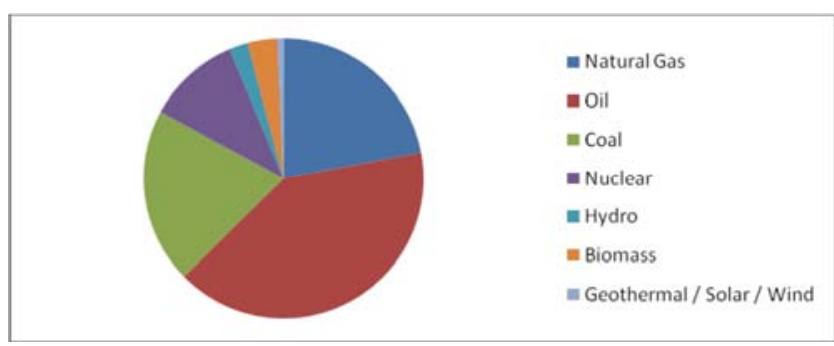

Figure 5. Energy mix in OECD countries. [25].

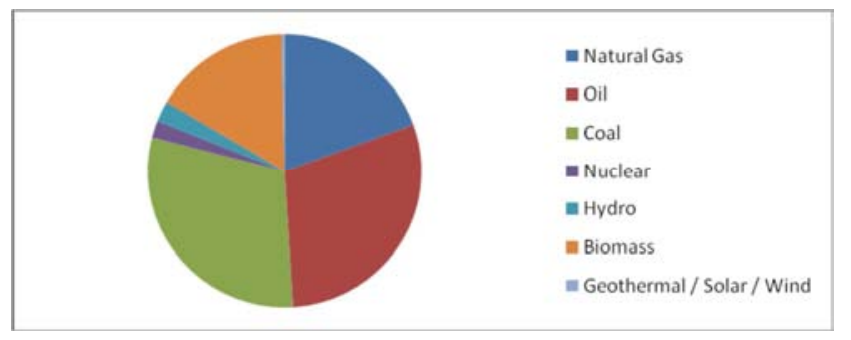

Figure 6. Energy mix in Non-OECD countries. [25].

Africa and other developing countries also depend strongly on biomass. In Ghana, the primary energy supply is mainly dependent on biomass, petroleum, and hydro. In 2015, oil contributed $44.48 \%$ to primary energy supply, followed by biomass $(37.87 \%)$, hydroelectricity $(5.27 \%)$ and natural gas $(12.38 \%)$ [26]. As revealed in Figure 7, there has been an overall $65 \%$ increase in the total primary energy supply between 2005 and 2015. This growth was led by oil, which doubled between the periods, followed by natural gas. Biomass supply remained essentially the same over the period, and hydro registered a slight decline [26].

There has been massive usage of trees and food crops for bioenergy. A key aspect of bioenergy, especially in West Africa is the relation of the bioenergy with sustainable forest management [9]. Acknowledging that forests were getting lost to the concerted pressures of harvesting for firewood and charcoal production, clearing land for cultivating energy crops, the commercial tree plantation industry was introduced [9].

In Ghana, final energy expended is dominated by biomass and petroleum products. Biomass, in the form of charcoal, firewood, and agricultural residue contributed $40 \%$, while electricity accounted for only $13 \%$. Petroleum products, including gasoline, diesel, LPG and jet fuel accounted for $47 \%$ (of about 7 million toe) of final energy consumed in 2015 [25]. As shown in Figure 8, there was an $81 \%$ increase in the total final energy consumed between 2005 and 2015. This growth was led mainly by petroleum products, which saw a $77 \%$ growth over the period. Biomass consumption was fairly stable, with electricity consumption growing at $62 \%$ beyond the 2005 level [25].

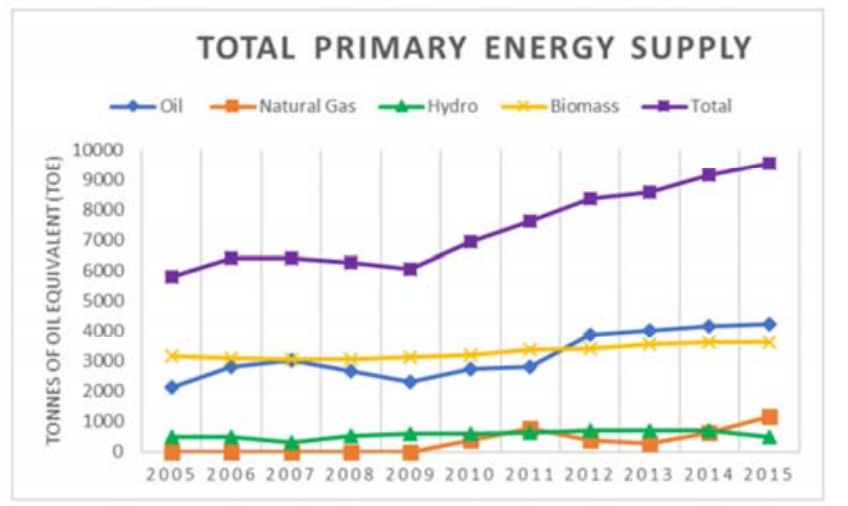

Figure 7. Total primary energy supply in Ghana, 2005-2015 Source: Energy Commission, Ghana, 2016.

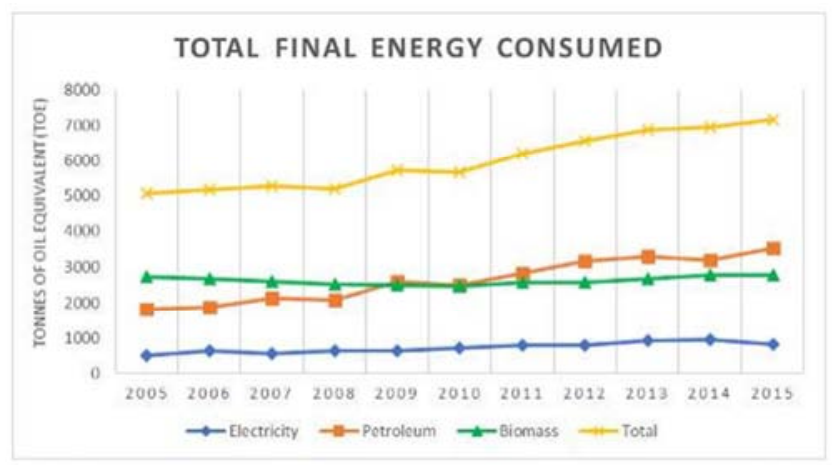

Figure 8. Total final energy consumed, 2005-2015 Source: Energy Commission, Ghana, 2016.

Energy Commission, Ghana, estimates that an additional capacity of about $200 \mathrm{MW}$ per annum is requisite to catch up with the growing demand in the medium to long term [26]. In line with the Ghana government's efforts to promote modern fuels for cooking, demand for woodfuel on the other hand, will increase by only $21 \%$ from 3,460 ktoe in 2015 to 4200 ktoe in 2030 as shown in Figure 9. Woodfuel demand is driven almost entirely by the household and small industry sector [26].

Clean and efficient cookstoves projects have been linked up to commercial tree plantations to produce clean charcoal. For a case in Ghana, the cultivation of eucalyptus trees on large-scale; tailored towards burning in power stations has been instituted. A sustainable forest is best achieved through community governance, building on traditional knowledge and practices of local communities, and focus on protecting forests. In Ghana, African plantations for sustainable development introduced a project to plant eucalyptus trees. The purpose is to use the tree species in electricity generation 
for a $60 \mathrm{MW}$ power plant to be put in operation from 2021. The power plant will rely on an annual supply of 600,000 $\mathrm{m} 3$ of logs from the eucalyptus plantation [9].

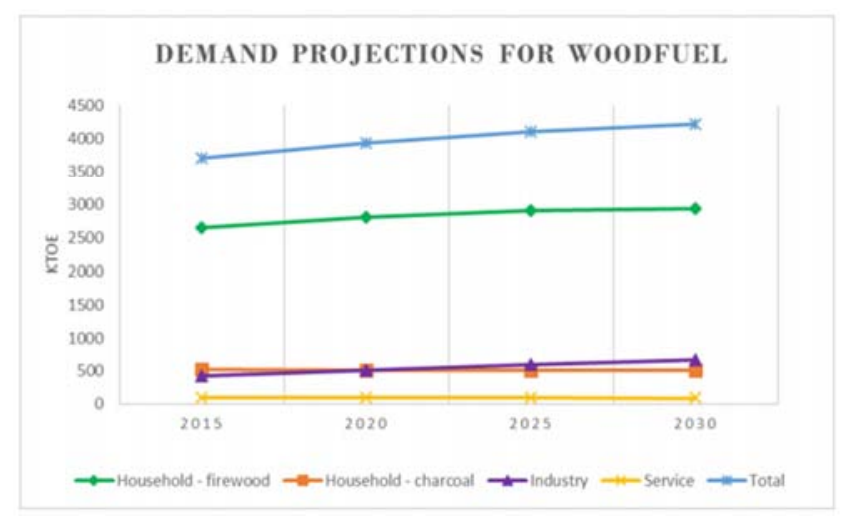

Figure 9. Woodfuel demand projections Source: Energy Commission, 2016.

In 2004, the total primary energy supply from renewable energy in Europe was $13.1 \%$ of the 11059 Mtoe of world total primary energy supply, $97 \%$ of which was biomass [27]. Biomass constitutes $11 \%$ of the total primary energy consumption globally [9]. For all renewable energy used, $80 \%$ goes into use as primary energy. This means only $20 \%$ of renewable energy used is subjected to conversion processes or transformed into higher grade energy (such as hydrochar, biochar, briquette etc) before use. It has been predicted that modern bioenergy has the potential to produce more than hydro in the years ahead [9]. New bioenergy markets have emerged because for households, small industries, cogeneration have had high-efficiency applications (in terms of solid biomass). A typical bioenergy approach is the use of pellets which has enhanced or created livelihoods in several countries. More than $85 \%$ of the energy consumed is biomass. The use of wood fuel presents an opportunity that works in tandem with improved forest management and enhancement of ecosystem. New trends and efforts are ones which have reduced the possibility of damaging forests and risking livelihoods. For woody biomass, the sources include smalldiameter trees, logging residues (slash, tops, limbs, materials left after harvesting conventional forest products), residues from mills and other wood waste forms [9]. Residue from logging could constitute an average of $35 \%$ of the entire forest tree used in logging. Short-rotation woody crops (SRWC) is one source of woody biomass which are cultivated using agronomic techniques in open fields [28].

For lack of access to modern energy, the potential challenges to a community are the length of time to pick up firewood and water, adverse effects of pollution, lack of health and education services (reliant on electricity supply and reliable energy supplies) etc. [9]. For Sub-Saharan Africa, dependence on biomass constitutes $61 \%$ of primary energy consumption. At least $95 \%$ of the household fuel use is wood fuel or charcoal. In times past, significant use of wood fuels was for use in brick-making (small scale activities). In some instances, traditional biomass use could be sustainable except that it cannot be sustainable for the longer term. The reasons are low-efficiency difficulty in controlling the level, and quality of energy services provided. A global transition to sustainable energy (i.e. modern bio-energy from traditional) is necessary in the developing world [9].

The nature of demand and local or community conditions determine the economic competitiveness of modern bioenergy [3, 9]. For instance, in places such as Pura in Southern India, there are both interventions in cultivating crops for liquid biofuel production, cogeneration applications, and biogas for electricity systems [3,9]. This is because, unlike rural or remote communities where there is high demand for cheap and low grade fuel, the communities are peri-urban and as a result, have increasing demand of higher quality energy, thus, giving room for biofuel production, cogeneration applications and biogas for electricity. It is apparent that energy use is strongly related to economic growth and poverty alleviation [29].

\section{Biomass Conversion Options}

Conversion of biomass to bioenergy either results in final products or building blocks for further transformations. There are different technologies in converting biomass to bioenergy, which calls for technical know-how and other factors such as infrastructure, market, full participation of critical players and policy incentives to facilitate bioenergy enterprises. There exist different categorizations of biomass conversion route. Amongst them are mechanical, physicochemical, biochemical and thermochemical. This type of classification is adopted in this chapter and discussed in the subsection.

\subsection{Mechanical and Physicochemical Conversion}

Mechanical extraction in biomass conversion includes briquetting, pelletization and extraction of oil from plants [30]. Briquetting and pelletization involve converting a biomass material into a high energy density product: briquettes and pellets. Briquetting consists of an application of pressure to a biomass material; transforming it into a compact agro-mate. The resulting energy product has high energy density and is used for direct combustion. Pelletization takes the same approach, except that it makes use of some smaller dies for the pressure treatment. Biodiesel production involves mechanical extraction of oil from seeds, followed by transesterification reaction process. The biodiesel could be used directly or treated for different specific applications. The mechanical extraction of oil could be either through solvent extraction or hydraulic press extraction $[3,9,30]$.

\subsection{Biochemical Conversion}

Biochemical conversion makes use of biological organisms and enzymes (biological catalysts), transforming biomass into energy and some value-added products. Most of the time, the energy produced is ethanol $[5,28]$. Biological conversion of biomass to bioenergy takes one of two routes: fermentation and anaerobic digestion [3, 4]. In fermentation, 
feedstocks used are sugars and starch. Catalyst is used to convert sugars into alcohol [36]. In place of sugars, lignocellulosic biomass could be used. The process involves hydrolyzing the feedstock (breaking down into essential components) before fermentation. Although the hydrolysis process occurs under enzymatic action, acid hydrolysis is more effective, and thus provides a better mature conversion medium.

Nonetheless, enzymatic hydrolysis as well gives a better long-term option in respect of technical efficiency. In the case of lignocellulosic conversion, residues could serve as a fuel for the energy required and surplus energy. Anaerobic digestion, on the other hand, makes use of micro-organisms in producing methane gas from varied biomass sources given a limited oxygen medium. Substrates for the conversion include household organic waste, manure, agricultural/forest residues, and similar organic waste streams [9, 36, 37].

Bioenergy crops such as maize, cassava, wheat can be used as substrates, in which case, they should be dedicated energy crops [9]. The methane gas produced is applicable in use for direct heating or cooking electricity generation or both heat and power. Biogas is compressible to take the form of natural gas, so they are used as transport fuels. An exciting conversion step is the use of vinasse (waste stream from bioethanol production) for anaerobic digestion. Figure 10 is a general schematic of biomass biochemical conversion adopted from Decker et al. [5].

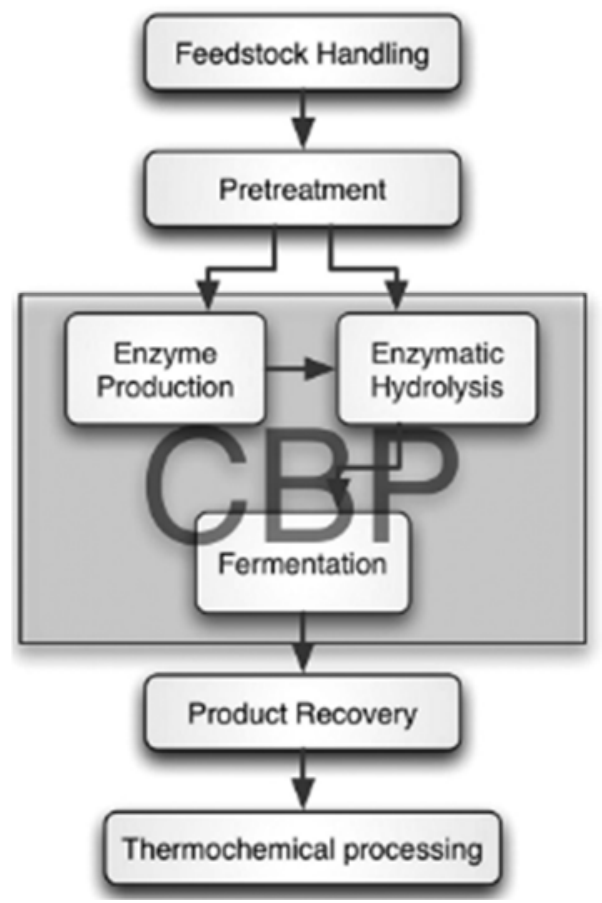

Figure 10. Biomass biochemical conversion process flow [5].

Small-scale heat and power technologies that can help to fulfil the needs of rural communities based on biochemical conversion, have been introduced in some African countries [31]. Examples include a Kenyan small-scale power generation system which is useful for rural cottage industries or community agro-industry development, and a Ugandan small-scale integrated power and heat generation system [31].

In Africa, the first grid-connected biogas power system, with 2 MW of capacity, started operation in 2017 in George Farm, Nairobi, Kenya. It meets the needs of about 6000 rural families [32, 33]. Consistent biomass feedstock availability is key to providing stable power generation. A few biogas energy plants have started operations. The company set the selling price of the electricity lower than that of diesel fuel to ensure feasibility [31].

\subsection{Thermochemical Conversion}

The thermochemical conversion uses heat and chemical catalysts to produce useful energy and value-added products from biomass [5, 36, 38]. Figure 11 is a general schematic of biomass thermal conversion adopted from Deckler et al. [5]. The main technologies of thermochemical conversion of biomass and biodegradable waste to energy and other valueadded products include combustion, pyrolysis, gasification, and liquefaction.

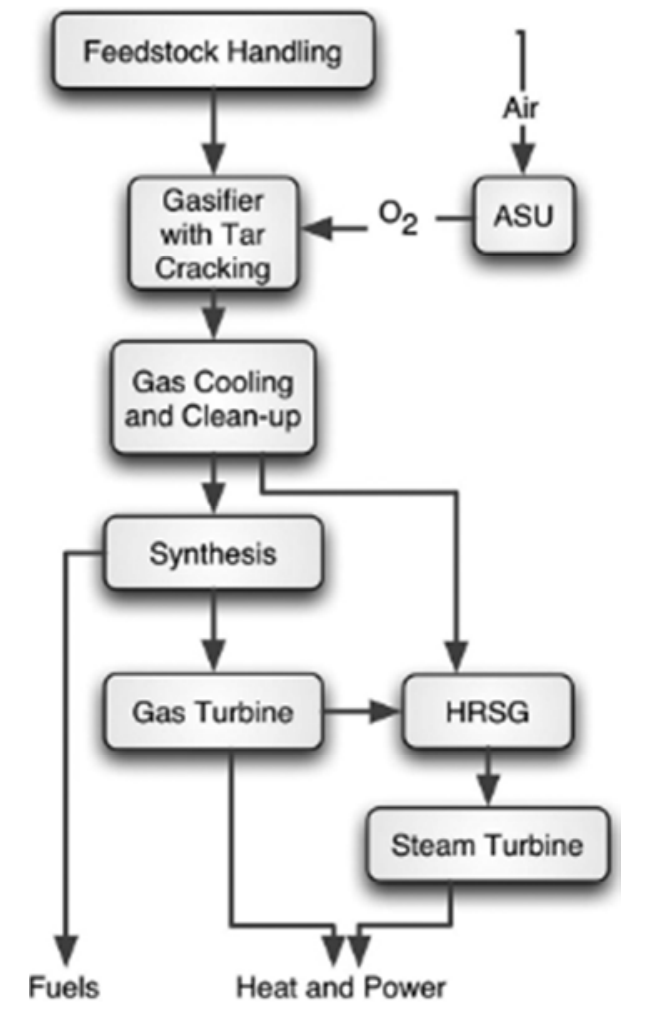

Figure 11. Biomass thermochemical conversion process flow [5].

\subsubsection{Combustion}

In the simplest form, combustion of biomass can occur in a combustion chamber of a furnace [3, 9]. Approximately $90 \%$ of the energy obtained from the biomass fuels, is in diverse forms. Especially for commercial and industrial scales, feedstock ranges from woody biomass and municipal solid waste (MSW). The combustion process yields hot gases as biomass fuel that has $85 \%$ of fuel's capacity (energy content). An adaptable combustion approach is a biomass-fired boiler which generates electricity, mechanical energy or heat from 
biomass $[3,9,36]$. Co-firing, is a combustion process which involves the burning or combustion of biomass materials, with other fuels, usually, fossil (coal or lignite) [3, 9]. For instance, the blending of coal with biomass could be done in a wide range of proportions.

Village infrastructural power (VIP), is an organization that aims to increase opportunities in rural communities by providing reliable and affordable power to farmer groups, entrepreneurs and small and medium-size enterprises, through combustion of biomass waste. VIP's platform technology is a modernised steam engine that produces threephase electricity (up to $10 \mathrm{~kW}$ ), mechanical power (up to 12 $\mathrm{kW}$ ) and thermal energy (up to $40 \mathrm{~kW}$ ). Biomass waste is the fuel source for the engine, which consumes roughly $2,040 \mathrm{~kg}$ per hour, depending on the fuel type [31]. The engine has a $60 \%$ energy conversion rate and has a simple design that is easily operated, repaired and maintained in a village setting [31]. By combining this energy platform with ancillary equipment like irrigation pumps, grain mills, dryers, refrigerators and pasteurisers, rural-based businesses are able to increase production and perform primary processing closer to the production site [31]. Customers use the technology in combination with fruit and vegetable dryers and mills to preserve fruits and other food crops. Through the technology, post-harvest losses of highly seasonal and perishable crops are drastically reduced. The first pilot users reduced their losses by $80 \%$ and increased their income fivefold in their first season of using a VIP-powered dryer and milling solution [31]. Figure 12 shows a picture of Village Industrial Power in operation at a community.

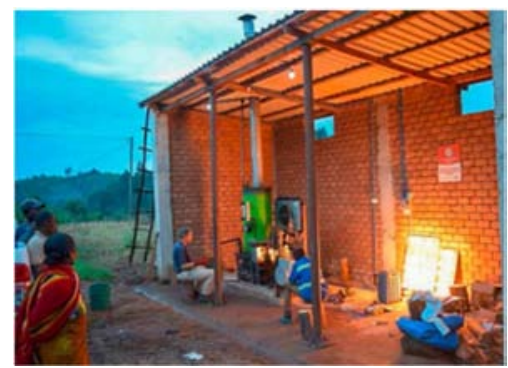

Figure 12. Village Industrial Power System for heat and power generation. Source IRENA 2018.

\subsubsection{Gasification}

Gasification involves heating biomass in the presence of air, oxygen and/or steam to produce a gas mixture: useful as an energy source and convertible to some fuels and products [5]. Gasification is an alternative to direct combustion [9]. Advantageous over other biomass conversion systems is that, it is compatible with advanced turbine designs and heatrecovery steam generators, thus, yielding high energy efficiency [30].

The gasification unit is comprised not only of the gasifier, but also of two other main components, i.e. the syngas cooling and cleaning systems, in addition to all the other complementary devices (dedicated to biomass storage and pretreatment, ash disposal, etc.). Syngas at gasifier output is rich in impurities which have to be removed. Figures 13 and
14 respectively show a waste to energy plant diagram, and a biomass gasification plant.

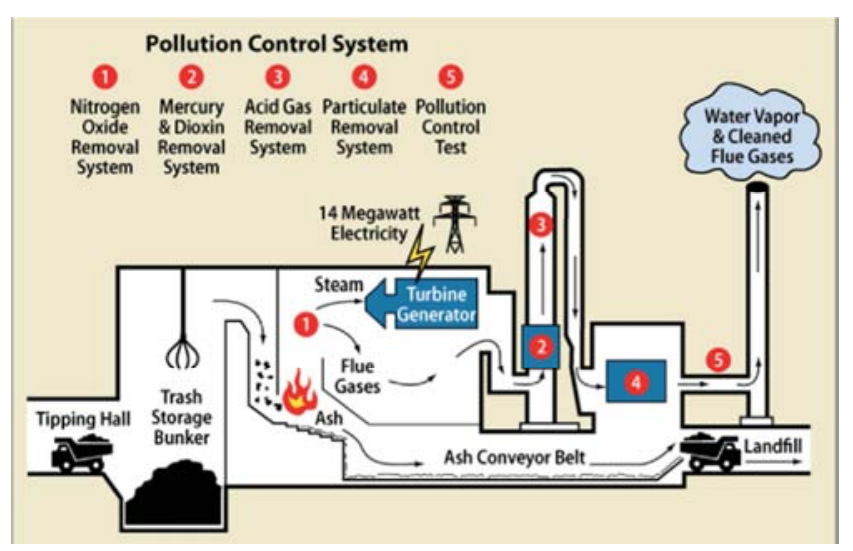

Figure 13. Waste to energy plant diagram. Source: ecomaine.

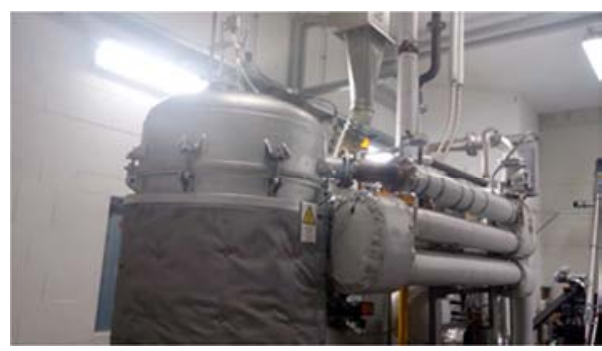

Figure 14. A biomass gasification plant. Source: Authours'own.

Another company, Mandulis Energy has also developed a biomass gasification system in co-operation with Imperial College London, by thermochemical conversion of solid biomass in a low-oxygen environment into a syngas, with biochar as a by-product [31]. The syngas is used to drive a gas or stream turbine to generate electricity as well as heat [31]. The biochar is used to make briquettes as an alternative to wood charcoal.

Mandulis Energy has already started an 8 MW (16 sites of $500 \mathrm{~kW}$ ) of off-grid and $20 \mathrm{MW}$ on-grid power generation sites. Off-grid power generation has investment by the Founders, Angels \& Norgesvel/Nordic Climate Facility, GIZ GmBH [31]. On-grid generation is approved by the Ugandan government and the Uganda Electricity Regulatory Authority [31].

\subsubsection{Pyrolysis}

Pyrolysis is the thermochemical decomposition of organic matter at high temperatures in the absence of oxygen. Pyrolysis results in a wide range of products: from transportation fuel to chemical feedstock. The process runs on most biomass feedstocks, with higher efficiency using cellulose. The process gives three major energy products (in varying amounts): char, oils and gases. A pyrolysis process could be flash or fast. The latter produces higher value products, while the former produces high oil yields [3, 36]. Balance of plant ensures the required product output.

Worldwide, there are several companies with early commercial fast pyrolysis technologies, with current and planned commercial scale plants in the range of 20 to 40 $\mathrm{Ml} / \mathrm{yr}$ [34]. These plants are, however, largely located in 
North America and Europe. Some companies focus on pyrolysis as a waste treatment technology, such as Beston, who have deployed such a plant in Nigeria [34], and GrahamTek, who are planning a plant in South Africa [34]. The use of fast pyrolysis to produce bio-oil in sub-Saharan Africa (SSA) remains extremely limited.

A wide range of feedstocks can be used for fast pyrolysis, as long as they are pretreated to the required moisture content and particle size. So, in theory this technology could be widely replicated across SSA. The composition of the feedstock (e.g. ash content) can have an impact on the yield of bio-oil [35].

\subsubsection{Liquefaction}

Liquefaction is a low temperature and high-pressure thermochemical process during which biomass is broken down into fragments of small molecules in water or another suitable solvent. These light fragments, which are unstable and reactive, can then repolymerise into oily compounds with various ranges of molecular weights. Lignocellulosic biomass is the most widely used raw material for bio-oil production through liquefaction. Balance of plant ensures the required product output.

\section{Forest Biomass Energy-Based Enterprises and Policies for Sustaining the Enterprises for Community Livelihoods}

\subsection{Forest Biomass Energy-Based Enterprises}

A sustainable livelihood is resilient to stress, shocks, and either maintains or enhances abilities and assets not undermining natural resource base [9, 30]. Measuring a sustainable livelihood is through framework indicators of assets, transforming structures and process, context, strategies and outcomes. In other approaches, indicators used in assessing livelihoods are:

1) Poverty reduction

2) Creation of working days

3) Natural resource base sustainability

4) Livelihood adaptation, vulnerability and residence

5) Well-being and capabilities
An assessment of bioenergy and bioenergy economics establishes that there are a number of jobs created by bioenergy industries [9]. More importantly, the bioenergy jobs are created in rural areas, where high levels of poverty occur. Consequentially, it serves to reduce the occurrence of migration [9]. Beyond the rural areas, peri-urban communities (those between cities and villages) take advantage of resource-based sources to learn a livelihood. Such include charcoal production and distribution as well as firewood gathering in rural areas. Making charcoal production, sale and distribution, a significant source of livelihood are both for the rural and peri-urban areas [3, 9]. Cost-effectiveness of biomass is quite mixed for countries which have no market support systems for bioenergy [27]. Figure 15 shows a comparison of energy costs from gas and pellets with future projections [27]. The cost of gas has always been more than the cost of pellets, and both costs have increased over the years (Figure 15). Table 1 shows the heating price comparisons, from the UNDP-GEF project in Slovakia [27]. The Heating efficiency typically varies between $65 \%$ and $98 \%$ depending on the fuel type, being lowest for brown coal (60\%) and highest for electricity (98\%). The efficiency of pellets is also high (90\%) with relatively lower cost than that of gas and log wood (Table 1). The basic energy cost is not enough data to determine the most cost-efficient way to heat a space because even with a lower-cost fuel in hand, if the efficiency of the heating is low, and the energy content of the fuel is also low, one may be wasting the energy or not receive enough energy.

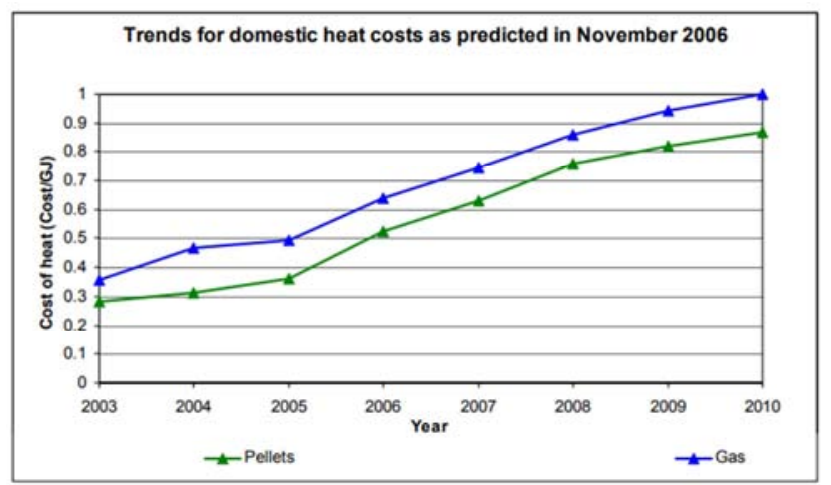

Figure 15. Comparison of energy costs from gas and pellets with future projections [27].

Table 1. Heating price comparisons from the UNDP-GEF project in Slovakia [27].

\begin{tabular}{|c|c|c|c|c|c|c|c|c|}
\hline \multirow{2}{*}{ Fuel } & \multirow{2}{*}{ Unit } & \multirow{2}{*}{$\begin{array}{l}\text { Price } \\
\text { Sk/unit }\end{array}$} & \multirow{2}{*}{$\begin{array}{l}\text { Energy content } \\
\text { MJ/unit }\end{array}$} & \multirow{2}{*}{$\begin{array}{l}\text { Efficiency } \\
\% \\
\end{array}$} & \multirow{2}{*}{$\begin{array}{l}\text { Operating costs } \\
\text { Sk/yr }\end{array}$} & \multirow{2}{*}{$\begin{array}{l}\text { Amount of Fuel } \\
\text { required }\end{array}$} & \multirow{2}{*}{$\begin{array}{l}\text { Total cost / GJ } \\
\text { Sk/GJ }\end{array}$} & \multirow{2}{*}{$\begin{array}{l}\text { Total cost / year } \\
\text { Sk/yr }\end{array}$} \\
\hline & & & & & & & & \\
\hline Log wood & $\mathrm{kg}$ & 3 & 13.7 & 80 & 7,000 & 9,124 & 344 & 34,372 \\
\hline Brown coal & $\mathrm{kg}$ & 3.4 & 17.2 & 60 & 3,500 & 9,690 & 364 & 36,466 \\
\hline Coke & $\mathrm{kg}$ & 8.1 & 27 & 65 & 2,500 & 5,698 & 487 & 48,654 \\
\hline Pellets & $\mathrm{kg}$ & 6.8 & 17.5 & 90 & 5,000 & 6,349 & 482 & 48,175 \\
\hline Gas & $\mathrm{m}^{3}$ & 14.7 & 33.7 & 90 & 1,500 & 3,297 & 500 & 49,967 \\
\hline Electricity heat accumulator & $\mathrm{kWh}$ & 1.81 & 3.6 & 96 & 5,050 & 28,935 & 574 & 57,423 \\
\hline Propane-butane & $\mathrm{m}^{3}$ & 29 & 46.5 & 90 & 4,000 & 2,389 & 733 & 73,295 \\
\hline
\end{tabular}

Figure 16 shows a breakdown of renewable energy jobs created globally by renewable energy technology [39].
According to statistics available with the International Renewable Energy Agency (Figure 16), aside solar 
photovoltaic, liquid biofuels top with 2,063,100 of jobs created globally from renewable energy technologies. Aside liquid biofuels, solid biomass created 787,100 jobs. Three hundred and thirty-four thousand jobs were created by biogas technology and 41,100 by the municipal solid waste industry.
These job employments are out of the ten million jobs that were created globally by the end of 2018. In effect, out of the ten million jobs created by the end of 2018 globally, $3,225,300$ were created by the bioenergy market.

\section{Renewable Energy Employment by Technology}

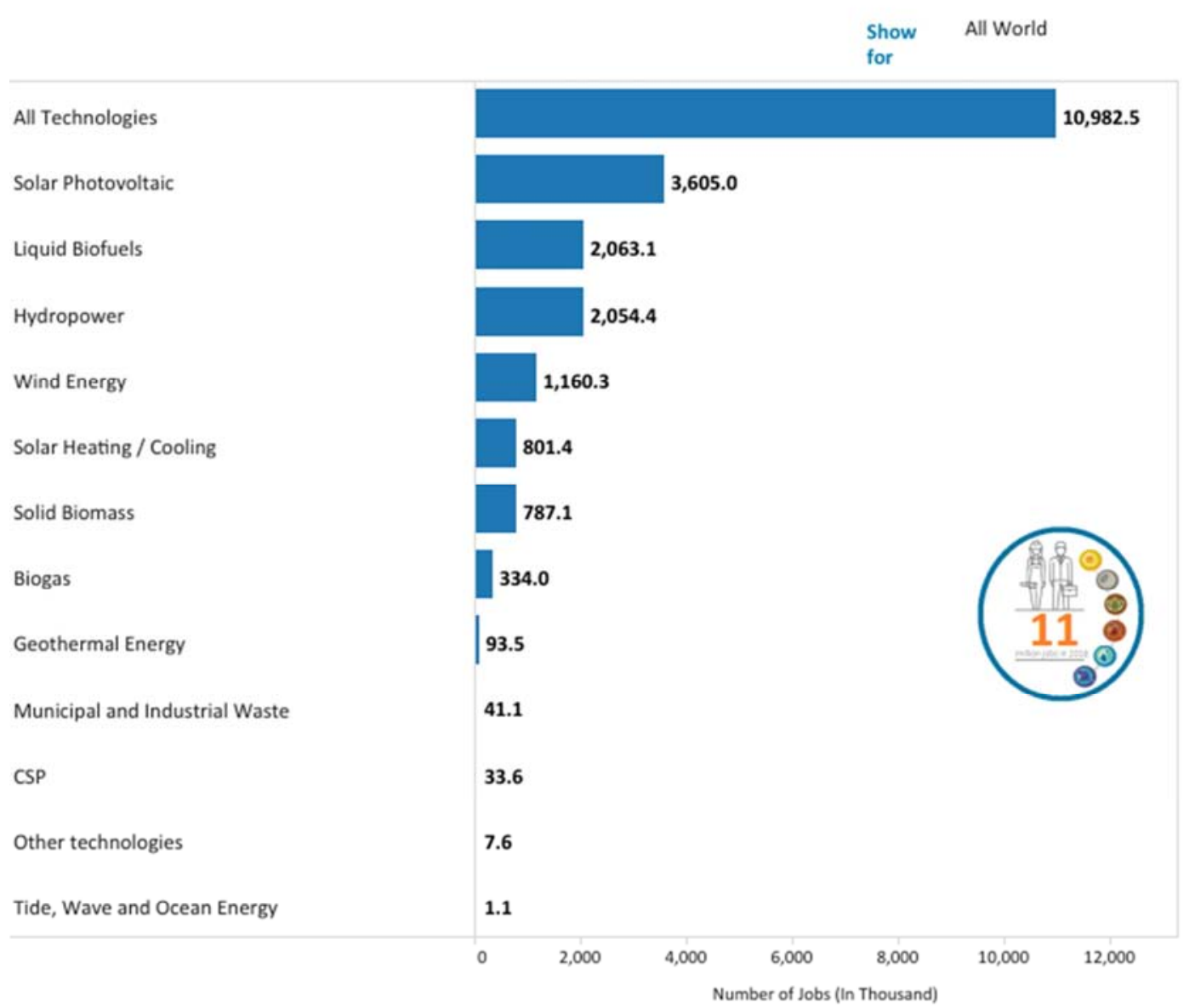

Figure 16. Renewable Energy Jobs by Technology [39].

According to the International Energy Agency (IEA), three perspectives matter to bioenergy market and business creation: research, development, and deployment [27]. In other words, technology, demonstration and market learning, market barriers, market transformation are the forces that drive bioenergy market transformation and creation of businesses. The bioenergy market can make significant impacts and create sustainable livelihoods when the efficiency of technologies is increased, costs are reduced and, industries mature [27]. Self-sustaining sectors in manufacturing, installing and maintaining bioenergy systems become imperative. Bioenergy infrastructure, market and development promote energy decentralization [27]. Local dwellers, therefore, get easy access to energy sources in making a living and will include, for instance, the use of biodiesel to power generators instead of fossil fuel or grid power. In some cases, there have been a rapid degradation of forests and the soil in terms of short-term profit [9]. This is dealt with when there are carefully managed strategies of growth; thus, keeping the resource base and maintaining them in some cases.

Biomass provides unique development opportunities in rural areas. BIOBUSINESS is a European initiative that was set up to focus on creating and growing biomass related enterprises: to regenerate the economy of the regions concerned including very deprived rural lands. The project is to ensure that partners, energy management agencies, public administrations, regional industrial development agencies join forces with renewable energy-related SMEs in creating scenarios of a critical mass of new enterprise. The results was that; the project triggered 169 new jobs; expecting more in the medium to long-term [40]. Thirty-seven new businesses were created and extended, with more expected in the medium and long-term [40].

The United Nations Development Program-Global Environment Facility (UNDP-GEF) biomass projects (tailored to Europe and the Commonwealth of Independent States (CIS)) looked at the use of wood residues produced by wood processing and the forestry in providing heat [27]. For demonstration projects that were rolled out were aimed at 
reducing cost, and technical barriers were hinged on technology. This project is one that supported the biomassfired district heating in Europe. In that case, jobs were created in varying forms: from the local or rural communities (supply of biomass) through to the professionals involved in generating heat. Interventions in biomass-based energy enterprises have estimated to create jobs numbering 250,000 to 300,000 while stabilizing rural areas in the European Union. Ballard-tremeer, 2007 [27] estimated that achieving $20 \%$ of renewable energy has the potential to create jobs in Europe and develop novel technology-driven companies. Table 2 summarises some selected biomass applications and how they play out in creating livelihoods.

Table 2. Income generating values for different biomass applications [36].

\begin{tabular}{ll}
\hline Energy Services & Income Generating Value \\
\hline Transportation & Market Access, Service Providers, Policy Makers, Public Transport \\
Illumination & Increased working hours \\
Irrigation & Better yield, Greater reliability, Higher value crops; Growing during periods when market prices are higher \\
Grinding, milling, husking & Value addition through the processing of agricultural commodity \\
Drying, Smoking (Heat Preservation) & Creation of value-added product, Preservation of produce for higher value markets \\
Extraction & Production of refined oils or distillates from biomass, seeds or fruits \\
Refrigeration, Ice- making (Cold Preservation) & Preservation of produce to allow the sale to higher-value markets Production \\
Battery charging & Wide range of services for end-users \\
Telecommunications & Access to market news, Weather information, Business and Financial service providers and policy \\
\hline
\end{tabular}

Cherni, Diaz-chavez, Valatin (2004) [41] report that for developing countries, past years saw to the development of sizeable infrastructural development in rural communities. Most importantly is rural electrification mostly involves offgrid solutions in such cases. However, impacts have not been relatively positive. A lot more rural folks still do not have access to clean and modern sources of energy: bioenergy. The non-access to clean energy gives impetus to the use of bioenergy as an ideal solution for populations in rural areas, particularly with relevant natural resource abundance. The World Bank that people living in poverty do only care about access to food, shelter, improved standard of life (characterized by health, care, education, transportation); all of which could be addressed through the provision of energy solutions [41].

While Ghana's situation slightly differs from the general picture for developing countries, it shares a very clear similarity. There is abundance of biomass resources for energy generation but the resource and its applications are underdeveloped. According to a nationwide mapping of stakeholders in the clean cookstove value chain in Ghana, 70\% of Ghana's total primary energy supply is wood fuels (firewood and charcoal) [42]. It resulted in the creation of the Ghana Alliance for Clean Cookstove (GHACCO) in 2012. The project had a target of fostering the adoption of clean cookstoves and fuels to about four (4) million households in Ghana. The project was also aimed at supplying five (5) million cookstoves by 2020 [42]. This project encompasses livelihoods of people around: stove manufacturing, fuel production, financial institutions and international donor agencies, distribution and retails of cookstoves and fuels, the supply of raw materials, and training and research institutions [42]. The study found seven industries that provide support to the cookstove industry, among which are the United Nations Development Programme (UNDP) and Netherlands Development Organisation (SNV). Their interventions have enhanced the use dependence of wood fuel sourced from the forest to biomass residues in Ghana [42].

\subsection{Policies for Sustaining Forest Biomass Energy-Based Enterprises}

In developing strategies for bioenergy development, it is necessary to consider the socio-economic priorities of the geo-political area, the overall resource base availability and the part of such resource base which is harvestable for bioenergy usage [9]. For a broader consideration, there is the need to look at the strategy to create, maintain and enhance the sustainable livelihood, specifically for persons in local communities of developing countries. Other key persons are those in areas that are ecologically, socially and economically connected to the local or regional communities. Generating bioenergy and its impact are strongly linked to several and contradictory policies [4]. One policy direction, which has not yielded the appropriate results is that there has been a quest to move towards biomass power stations in providing electricity for heavy industry and biofuel plant to power vehicles. While this happens, homes and communities have not had access to cleaner and safer energy. Policies should be tailored in a manner that economic resources are relocated to favour bioenergy for households. This should be augmented by ensuring full participation of critical players. This is a sure way to give communities and households access to cleaner and safer energy [27]. Support mechanisms should be used to provide the least cost for biomass and policy obligations. This will shift the burden of renewable financing to sizeable private sector utilities [27]. If biomass energy development policies are structured this way then they have the potential of enhancing sustainable energy use [27].

Being a party to the United Nations Framework Convention on Climate Change (UNFCCC), countries like Ghana and Nigeria are exploring renewable energy options with a focus on biofuels (producing ethanol that can blend with transport fuels). In recent times, Nigeria has signed memorandum of understanding (MOUs) to put up ten or more large biofuel complexes [2]. One of such initiatives is planned to engage 5,000 farmers to meet 350 tonnes per day of 
biofuel. Using policies and established institutions to support communities and people is crucial in developing strategies to improve livelihood, and will involve enhancing agricultural productivity, diversifying livelihoods, and search for livelihoods elsewhere [9]. This framework thus, highlights the essence of expanding bioenergy production. In some cases, the bioenergy expansion is for local markets only, and in other circumstances the expansion is for export markets only. In other situations, the expansion is for both local and export markets. A critical approach is to intensify the productivity of food crops; in which case, giving room for land that can be used in bioenergy production [9]. A diversification strategy will be useful and involve gathering and sale of biomass residues either to industrial buyers or household buyers. This strategy would be an approach to augment other income sources and a buyer for the period where food markets or climate conditions change. In the event where there is land that receives less rainfall, bioenergy crops could take over as they require water. The relationship between policy and creation of livelihood is complex; firstly, in respect of analytical models and secondly, how the practice is influenced in the promotion of sustainable livelihoods [9].

Some governments, for instance, the Nepal government has adopted implementation of efficient biomass technologies, use of biogas and improved cookstoves [6]. With this trend, livelihoods are affected or brought close to sustainability through reduced fuelwood consumption, improved health and consumption, reduced struggle for women, and improved social and physical facilities. In the use of biogas, the consumption of fuelwood is reduced by 2 tons/yr and workload by $1100 \mathrm{~h} / \mathrm{yr}$. The introduction and use of improved cookstoves tended towards increasing efficiency from $15-20 \%$ and GHG emission reduction of $1.09 \mathrm{tCO}_{2}$ eq/yr over traditional cookstove. Despite these potentials, some countries do face the challenge of effectively and rapidly disseminating efficient biomass technologies to sensitive isolated and remote areas [6].

Interventions in boosting the biomass business industry are first to create the local forest markets, thus, creating the platforms for buyers [28]. This encourages forest community to produce biomass for energy production. Policies should open up the bioenergy industry to allow for the creation of jobs, competition, efficiency, increased supply and consumption as against non-renewable energy sources. In promoting the use of biomass in energy generation, policies should be driven to enhance competition in the use of forest resources for timber, pulpwood, and other ecological services. These competitions ensure that there is the availability of biomass resources to use in energy generation. As the generation of biomass waste is increased from the operations of the forest industry, more biomass is made available for energy generation. Thus, the development of biomass markets largely depends on existing, improved and viable forest products industry. This is because a strong bioenergy industry survives on wood industry residues to a large extent. The sustainable use of biomass in energy generation involves relying on energy crops grown on agricultural or marginal lands, and biomass waste. The former has challenges with competition with food, and the latter solves the issue of environmental pollution. Utilization of biomass waste resources is therefore preferable in bioenergy generation. An example is in pellet manufacturing where manufacturers prefer using sawmill residue. However, in the case of inadequate supply, they may resort to the forest for forest residues and trees [28].

An emerging bioenergy technology should be one which meets demands for quality of raw material in terms of species, bark size distribution, contaminant limits, and content. This will give rise to market niches. Incentives on fossil fuels and other renewable energy sources will suffocate the forest bioenergy industry. Governments, therefore, will need to allow for realistic tariffs in those areas [28].

Different countries under the European Union introduced their own various interventions to promote biomass use. These interventions include feed-in-tariff, renewable obligations, fiscal incentives, tender schemes, and building directive to promote biomass heating. These interventions would as well work well, especially for parts of the world with high biomass potential. The biomass energy market has been driven by policies which would apply to other parts of the world and by that promote biomass energy-based business: tactical policies in diversifying the energy mix while increasing security of energy supply [27].

\section{Conclusion}

Biomass supply chains could provide sustainable livelihoods, especially in rural and peri-urban communities. Forest biomass energy and community development are strongly interlinked. Biomass-based energy enterprises have been sustained: economically, environmentally and socially, creating the necessary community livelihoods. International, regional and national bioenergy markets have evolved due to strategic policies and actions such as feed-in-tariff, renewable energy obligations, fiscal incentives, tender schemes, building directive to promote biomass heating. Further legislation on renewable energy on heating, targeted at increasing bioenergy intake has been introduced. However, biomass energy targets in creating sustainable livelihoods have not been achieved to the letter due to low enforcement of such policies.

\section{Conflicts of Interest}

The authors declare no conflicts of interest with respect to the publication of this paper.

\section{References}

[1] Miah D, Koike M, Shin MY, Akther S. Forest biomass and bioenergy production and the role of CDM in Bangladesh. Springer; 2020.

[2] Sequeira J, Delgado JV, Kpondzo K, Munnion O, Lovera S, Smolker R. Bionergy in West Africa: impacts on women and forest. 2019. 
[3] Kundu K, Chatterjee A, Bhattacharyya T, Roy M, Kaur A. Thermochemical Conversion of Biomass to Bioenergy: A Review. 2018. p. 235-68.

[4] Yilmaz S, Selim H. A review on the methods for biomass to energy conversion systems design. 2013. p. 420-30.

[5] Decker SR, Sheehan J, Dayton DC, Bozell JJ, Adney WS, Aden A, Hames B, Thomas SR, Bain RL, Czernik S, Min Zhang, and Himmel ME. Biomass Conversion. J. A. Kent (ed.), Handbook of Industrial Chemistry and Biotechnology, 2007. DOI 10.1007/978-1-4614-4259-2_33.

[6] Gurung A, Oh SE. Conversion of traditional biomass into modern bioenergy systems: A review in context to improve the energy situation in Nepal. 2013. p. 206-13.

[7] Dhillon RS, von Wuehlisch G. Mitigation of global warming through renewable biomass. Vol. 48, Biomass and Bioenergy. 2013. p. 75-89.

[8] Rossi AM, Hinrichs CC. Hope and skepticism: Farmer and local community views on the socio-economic benefits of agricultural bioenergy. 2011. p. 1418-28.

[9] Johnson FX, Rosillo-Calle F. Biomass, Livelihoods and International Trade Challenges and Opportunities for the EU and Southern Africa. 2007. 80 p. Available from: http://inis.iaea.org/search/search.aspx?orig_q=RN:42022438.

[10] FAO (2001). Plantations and wood energy. Report based on the work of D. J. Mead. Forest Plantation Thematic Papers, Working Paper 5. Forest Resources Development Service, Forest Resources Division FAO, Rome.

[11] Dale VH, Wright L, Kline KL, Perlack R, Graham RL, Downing M Interactions between bioenergy feedstock choices and landscape dynamics and land use. Ecol Appl 2011. 21 (4): $1039-1054$

[12] Hall J. P. Sustainable production of forest biomass for energy. The Forestry Chronicle. 2002 Vol. 78, No. 3.

[13] Kityo P. Productivity and utilization of Natural fuelwood Resources an evaluation of the current situation in some parts of Gaze province in Mozambique. 2014.

[14] CGIAR Research Program on Forests, Trees and Agroforestry. 2016.

[15] Environmental Protection Agency. Ghana's second national communication to the UNFCC. Accra: EPA/MEST. 2011.

[16] Energy Commission. Ghana, Woodfuels and Renewables. 2006.

[17] Derkyi NSA, Sekyere D,. Okyere PY, Darkwah NA, Nketiah SK. Development of Bioenergy Conversion Alternatives for Climate Change Mitigation. International Journal of Energy and Environment. 2011. Vol. 2 (3): 525-532.

[18] Präger F, Paczkowski S, Sailer G, Derkyi NSA, Pelz S. Biomass sources for a sustainable energy supply in Ghana - A case study for Sunyani. Renewable and Sustainable Energy Reviews 2019. 107: 413-424.

[19] Amoah M, Oduro M, Ohene M. Firewood consumption pattern, availability and coping strategies adopted to mitigate firewood scarcity: a case of rural households in Ghana, Forests, Trees and Livelihoods, 2015. DOI: 10.1080/14728028.2015.1052854.
[20] Amuah NEEH. The Potential of Agroforestry in Fuelwood Production for domestic and income Generation Activities. A case study of three communities in the Sunyani District of the Brong Ahafo Region Ghana. 2011.

[21] Luciana N, de Sousa G, Alves RM, Paulino AU, de Lima AE. The use of firewood in protected forests: collection practices and analysis of legal restrictions to extractivism. Acta Botanica Brasilica. 2019. 33 (2): 292-302. doi: 10.1590/0102$33062019 \mathrm{abb} 0050$.

[22] Sahoo, UK, Lalremruata J, Lalramnghinglova H. Assessment of fuelwood based on community preference and wood constituent properties of tree species in Mizoram, north-east India, Forests, Trees and Livelihoods, 2014. DOI: $10.1080 / 14728028.2014 .943684$.

[23] Webb EL, Dhakal A. Patterns and drivers of fuelwood collection and tree planting in a Middle Hill watershed of Nepal. 2011. www.sciencedirect.com.

[24] World Bioenergy Association, WBA Fact Sheet. Global Biomass Potential Towards 2035. 2016. Holländargatan, Sweden.

[25] International Institute of Environment and Development. Biomass energy -optimizing its contribution to poverty reduction and ecosystem services Report of an international workshop Parliament House Hotel, Edinburgh. October. 2010; 1-93.

[26] Energy Commission, Ghana. Ghana Renewable Energy Masterplan. 2019.

[27] Ballard-tremeer G. Opportunities for Biomass Energy Programmes - Experiences \& Lessons Learned by UNDP in Europe \& the CIS. 2007.

[28] Jacobson M, Ciolkosz D. A Primer on Woody Biomass Energy for the Forest Community. 2012.

[29] Ritchie H. and Roser M. "Energy". Published online at OurWorldInData.org. 2015. Retrieved from: 'https://ourworldindata.org/energy'.

[30] Singh A, Rawat KS, Nautiyal OP, Chavdal T V. Biomass To Fuel: Conversion Techniques. Energy Resour Dev Harvest Manag. 2016. 155-94.

[31] IRENA. Sustainable Rural Bioenergy Solutions in SubSaharan Africa: A Collection of Good Practices, International Renewable Energy Agency, Abu Dhabi. 2018.

[32] Kariyuki, D.“Africa welcomes its largest biomass powerplant”, Cleanleap. $2015 \mathrm{http} / /$ cleanleap.com/africa-welcomes-itslargest-biomass-power-plant.

[33] Tropical Power. "Gorge Farm Energy Park, at Naivasha, Kenya, is dedicated to showcasing leading-edge renewable technologies", 2018. www.tropicalpower.com/projects/gorgefarm-energy-park/ (accessed 11 August 2018).

[34] LBNet. An assessment of the potential for the establishment of lignocellulosic biorefineries in the UK. 2016.

[35] LTS International. Bioenergy for Sustainable Energy Access in Africa. Stakeholder Mapping and Literature Review Report. University of Edinburgh and E4tech. 2017.

[36] Sharma S, Meena R, Sharma A, Goyal P. Biomass Conversion Technologies for Renewable Energy and Fuels: A Review Biomass Conversion Technologies for Renewable Energy and Fuels: A Review Note. 2014. 
[37] US Department of Energy. Biomass: From Feedstocks to Final Products. US Dep Energy Energy Effic Renew Energy. 2016.

[38] Kucuk MM, Emirbas A. Biomass conversion processes. Energy Conversion Management. 1997: 151-165. https://doi.org/10.1016/0196-8904(96)00031-3.

[39] International Renewable Energy Agency. Renewable Energy Employment by Technology. 2020; 982.

[40] Barrio JCM. Business opportunities in the biomass sector for SMEs (BIO BUSINESS). 2020.
[41] Cherni JA, Diaz-Chavez RA, Valatin G. Renewable energy for sustainable rural livelihoods: Technical report for the Department for International Development. 2004. Available from:

https://assets.publishing.service.gov.uk/media/57a08cc2ed915 d622c001563/R8018Technicalreport.pdf.

[42] Ahiekpor JC, Ribeiro JXF, Rockson MAD, Bensah E, Antwi E. Nationwide mapping of stakeholders in the clean cookstove value chain in Ghana. Ghana Cookstove Sector Mapping Report. Centre for Energy, Environment and Sustainable Development. Final report. 2014. 